\title{
PREDICTION OF BEACH EROSION CAUSED BY REDUCTION OF FLUVIAL SAND SUPPLY DUE TO EXCESS SAND MINING AND BEACH RECOVERY AFTER PROHIBITION OF MINING
}

\author{
Toshiro San-nami ${ }^{1}$, Takaaki Uda ${ }^{2}$, Norikazu Ohashi ${ }^{3}$, Hitoshi Iwamoto ${ }^{3}$, Masumi Serizawa', \\ Toshinori Ishikawa ${ }^{2}$ and Shiho Miyahara ${ }^{1}$
}

\begin{abstract}
Long-term topographic changes since 1968 along the entire Shizuoka and Shimizu coasts including a $17 \mathrm{~km}$ stretch extending between the Abe River mouth and the tip of the Mihono-matsubara sand spit were investigated. Beach erosion of these coasts was triggered by the decrease in sediment supply from the Abe River due to excessive riverbed mining until 1967. After 1982/1983, natural sand supply from the river increased and accretion occurred on these coasts. Measured topographic changes were reproduced using the contour-line-change model considering changes in grain size. Not only the movement of the sand body but also the shoreline and bathymetric changes were numerically reproduced. The calculated results were in good agreement with the measured topographic changes.
\end{abstract}

Keywords: beach erosion; sand body; contour-line-change model; Shizuoka coast; sand mining

\section{INTRODUCTION}

The Shizuoka and Shimizu coasts have been severely eroded owing to the decrease in sand supply from the Abe River caused by excessive riverbed mining before 1967, with the eroded area expanding northward from the Abe River mouth (Uda, 2010). Then, sand deposition occurred from 1982/83 after the prohibition of riverbed mining, and the seawall exposed to waves as a result of erosion gradually became covered with sand. On the other hand, many detached breakwaters have been constructed as a measure against severe beach erosion on the Shizuoka and Shimizu coasts, which began in the 1970s. During this period, movement of the sand body with a propagating velocity of $260 \mathrm{~m} / \mathrm{yr}$ was observed shoreward of the detached breakwaters of the Shizuoka coast. Uda et al. (2008) predicted the movement of the sand body using the contour-line-change model, assuming a model beach with a uniform slope, given the bathymetry in 1983 before the generation of the sand body as a solid bed. Fukuhama et al. (2009) further applied the contour-line-change model considering changes in grain size to the same area to take into account the difference in the movement between fine sand deposited in the offshore zone and gravel deposited in the shoreline zone. Thus, in these calculations, part of the Shizuoka and Shimizu coasts with a straight coastline where detached breakwaters had been constructed was adopted and the movement of the sand body was analyzed. Furthermore, Nishitani et al. (2008) predicted the beach changes in the area where artificial headlands had been installed. However, because they selected only the area downcoast of where the movement of the sand body had
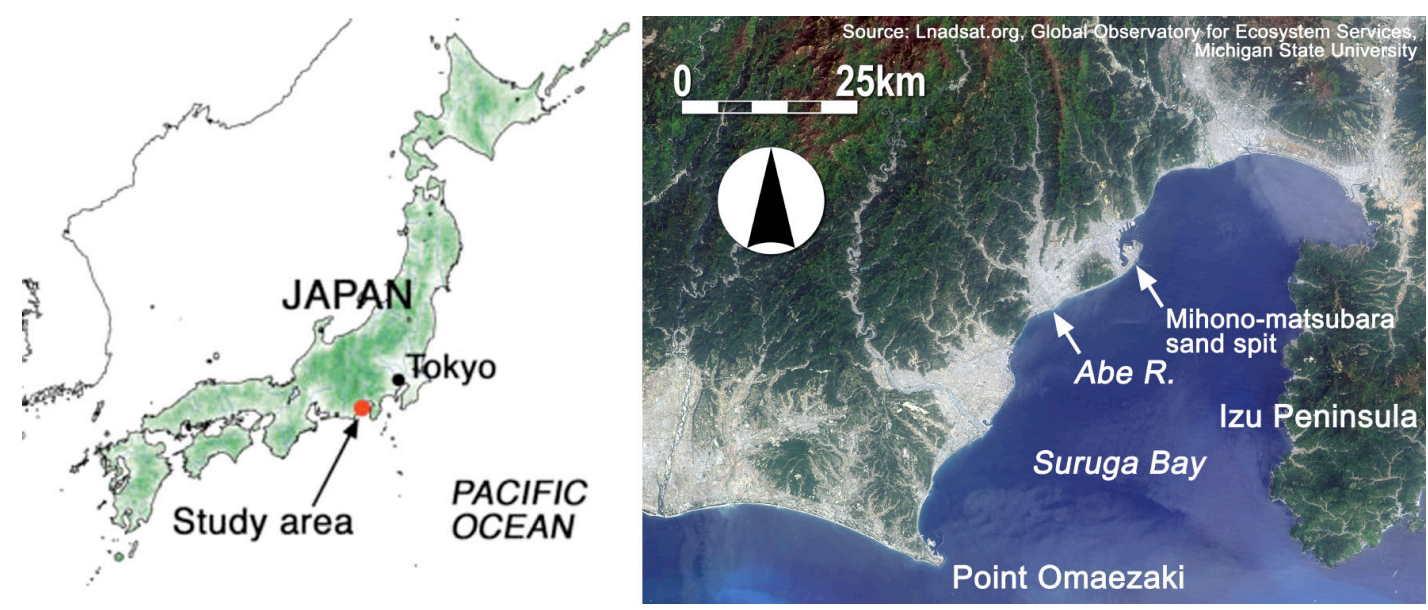

Figure 1. Location of Shizuoka and Shimizu coast facing the Suruga Bay.

\footnotetext{
${ }_{1}^{1}$ Coastal Engineering Laboratory Co., Ltd., 1-22-301 Wakaba, Shinjuku, Tokyo 160-0011, Japan

${ }^{2}$ Public Works Research Center, 1-6-4 Taito, Taito, Tokyo 110-0016, Japan

${ }^{3}$ Shizuoka Public Works Office, Shizuoka Prefectural Government
} 
been observed, the beach changes in this area in connection with the propagation of the sand body were not fully incorporated. In this study, analysis of the beach changes in the entire zone was carried out using the contour-line-change model considering changes in grain size, and not only the velocity of the sand body but also the changes in longitudinal profiles and shoreline position were reproduced. Given the bathymetry in 1968 before erosion as the initial topography, the long-term topographic changes until 2010 were first reproduced, and then future beach changes were predicted in case of artificially increasing the sand supply from the Abe River to recover the sandy beach on the Shizuoka and Shimizu coasts.

\section{BATHYMETRIC CHANGES OF ENTIRE COASTLINE}

The coastline of the Shizuoka and Shimizu coasts facing Suruga Bay smoothly protrudes around the Abe River mouth, then extends northward with a small curvature and turns around the tip of the Mihono-matsubara sand spit, as shown in Figs. 1 and 2. This sand spit started to form after the Jomon transgression of the sea about 6,000 years ago, and simulation of the evolution of the overall topography of the sand spit during this period is difficult because the boundary conditions are unknown. We therefore attempted to predict the future topography on the basis of the present topography. A curvilinear coordinate system was set along the present coastline with the origin at the left bank of the Abe River, and the alongshore distance from the origin was taken again on straight line, as schematically shown in Fig. 2. Along this axis, the tip of the sand spit, Masaki Point, is located at $X=$ $17.5 \mathrm{~km}$.

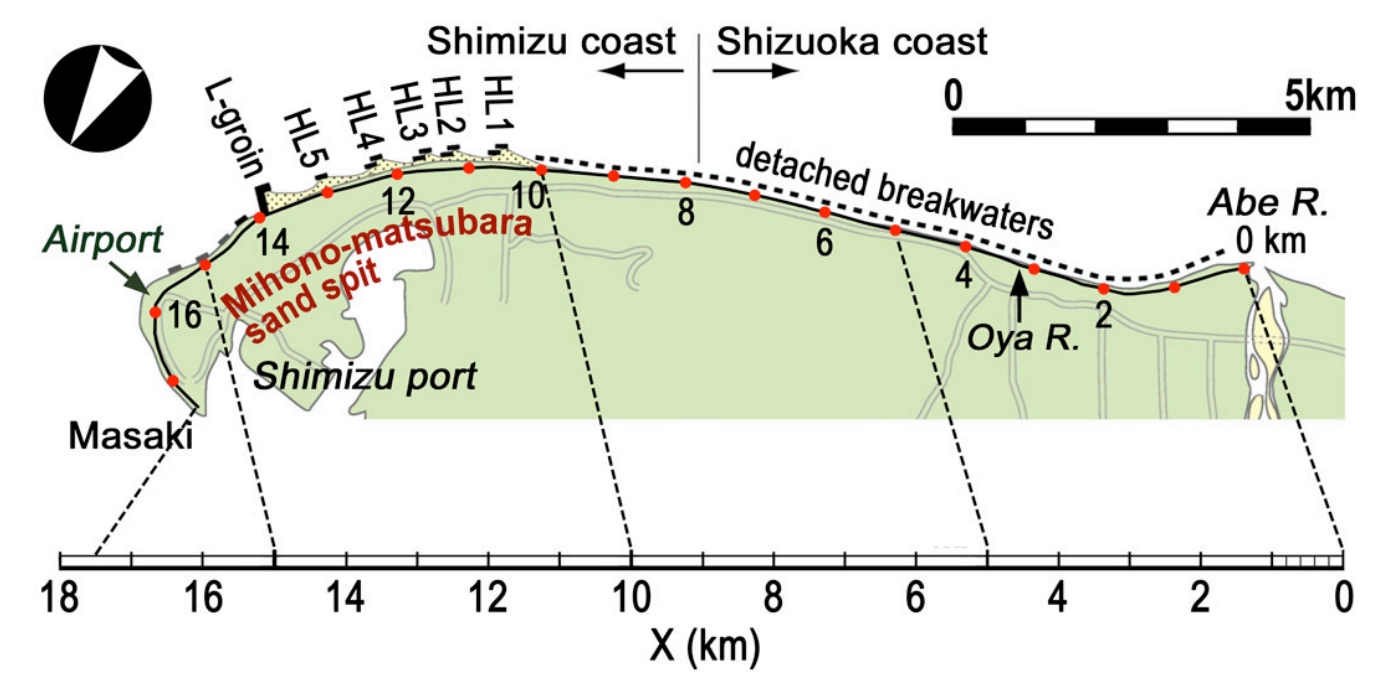

Figure 2. Alignment of structures constructed on Shizuoka and Shimizu coasts and expanded coordinate taken along coastline.

Figure 3 shows the bathymetric changes along this expanded coordinate system until 1995 and 2010 with reference to the bathymetry in 1985, in which the red and blue colors correspond to the accretion and erosion zones, respectively. As the general characteristics of the seabed topography of the study area, the foreshore slope is as steep as $1 / 10$, whereas in the offshore zone the seabed slope is as gentle as $1 / 50$ on the Shizuoka coast and in the southern half of the Shimizu coast. The offshore seabed abruptly becomes deep at $X=14 \mathrm{~km}$, where part of the northward longshore sand transport has been lost owing to offshore sand transport through the steep submarine canyon. An L-shaped groin was constructed at this location.

The gradual extension of the red zone in Fig. 3 shows that fluvial sand supplied from the Abe River mouth located at the right end of the study area was transported by northward longshore sand transport and mainly deposited behind the detached breakwaters. This sand deposition zone gradually expanded northward over time, as indicated by the propagation of the sand body (Uda et al., 2008). In contrast, the eroded zone expanded northward between $X=9$ and $X=13.5 \mathrm{~km}$ on the Shimizu coast, and sand deposition mainly occurred upcoast of the L-shaped groin constructed at $X=14 \mathrm{~km}$ because it blocked northward longshore sand transport. 

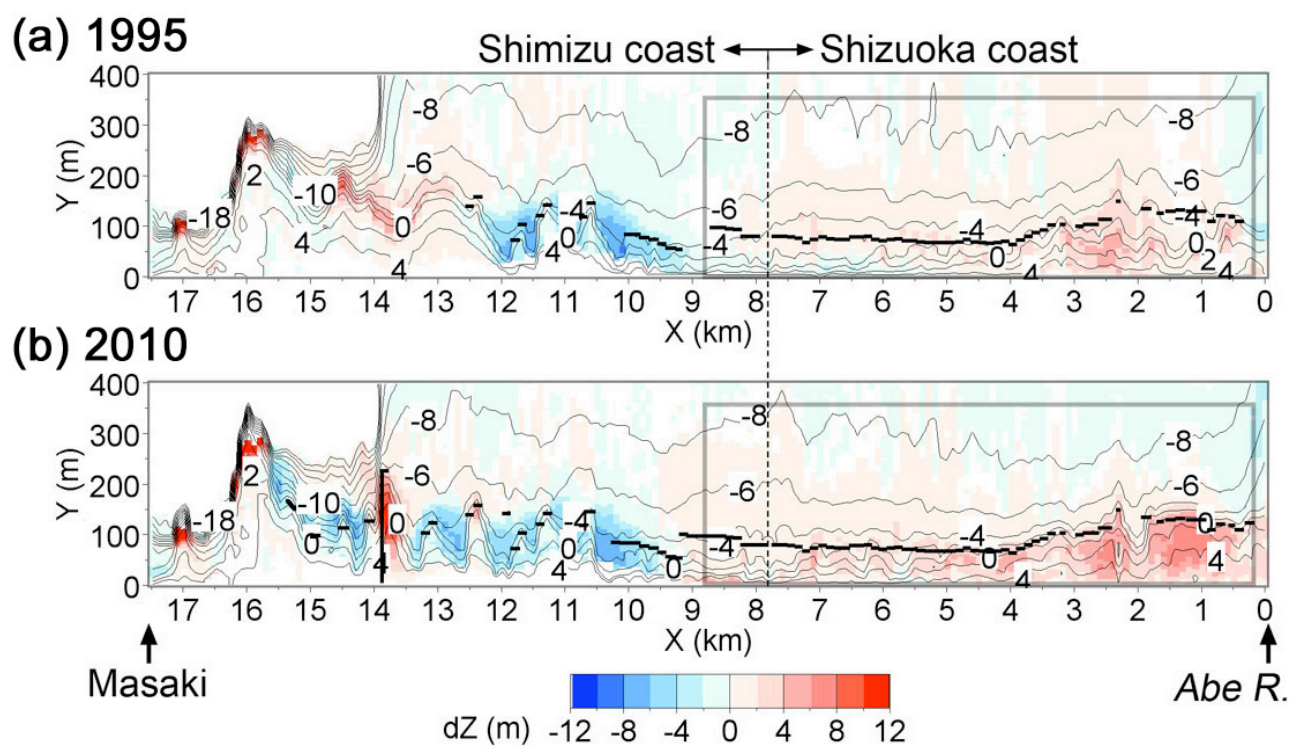

Figure 3. Bathymetries in 1995 and 2010 and changes until 1995 and 2010 with reference to bathymetry in 1985.

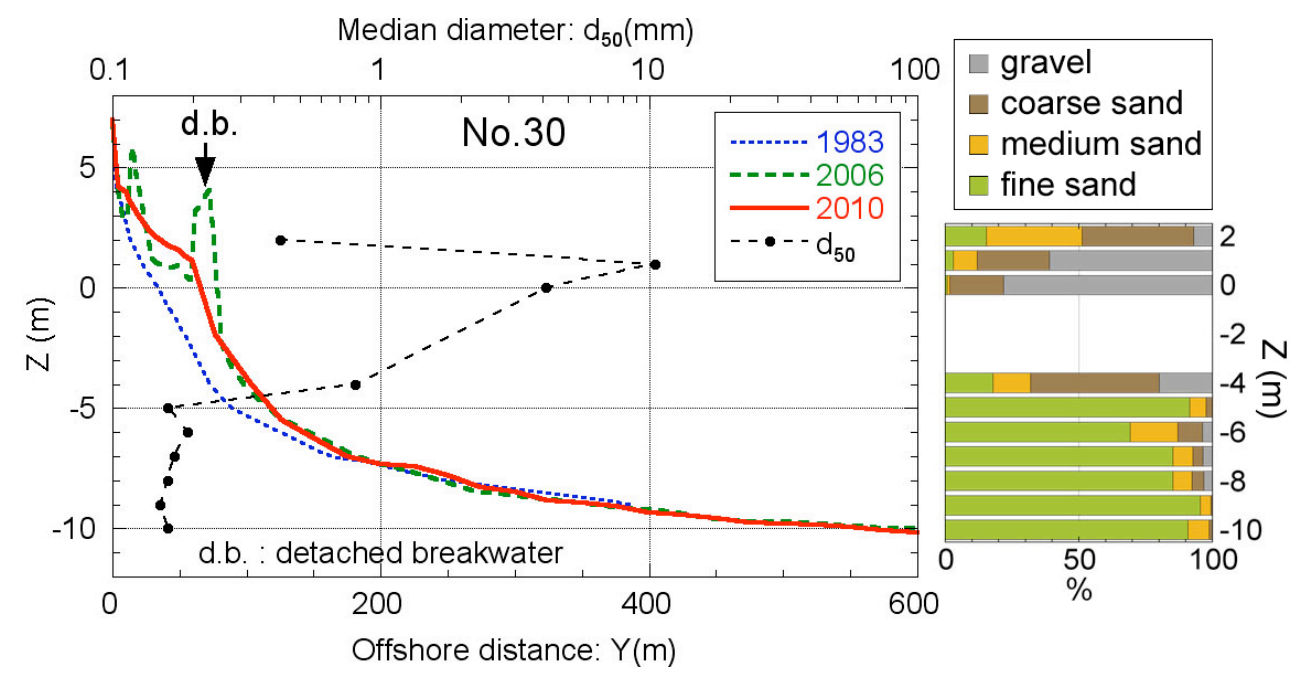

Figure 4. Change in longitudinal profile and depth distribution of $d_{50}$ along transect $X=4.8 \mathrm{~km}$.

Figure 4 shows the changes in the longitudinal profile between 1983 and 2008 and the depth distribution of the composition of bed materials (gravel and coarse, medium-size and fine sand) measured in August 2006 along transect $X=4.8 \mathrm{~km}$ across the detached breakwater. Along this transect, gravel and coarse sand mainly comprise the zone shallower than $-4 \mathrm{~m}$ and the foreshore slope is as steep as approximately $1 / 10$, whereas the seabed material is mainly composed of fine sand near -8 $\mathrm{m}$ and the seabed slope is as gentle as $1 / 50$. The characteristics shown in Fig. 4 were observed along other transects.

The change in the volume of sand deposited at depths between +5 and $-8 \mathrm{~m}$ in the rectangular zone shown in Fig. 3 since 1985 was calculated to determine the boundary conditions of longshore sand transport. Because gravel is mainly deposited in the zone shallower than $4 \mathrm{~m}$ depth and fine sand is deposited in the offshore zone in the calculation domain, the volumes of gravel and fine sand mainly deposited near the shoreline and in the offshore zone, respectively, can be obtained by separately calculating the sand volumes in these zones. Sand deposition in this area was caused by sand supplied from the Abe River under the conditions that the coastline was fully protected by the seawall constructed as a measure after the start of erosion and that hardly any sand underwent longshore 
transport. This means that the volume of sand deposited in the area between the Abe River mouth and the tip of the sand body is approximately equal to the sand supply from the river.

The total volume of sand deposited in this area divided by the number of years gives annual sand supply from the river. Therefore, except in the vicinity of the Abe River mouth, where there is a large variation in the seabed topography, the change in sand volume between $X=0.2 \mathrm{~km}$ and $X=8.8 \mathrm{~km}$, where the tip of the sand body reached until 2010, was investigated, as shown in Fig. 5. Here, the sand volume was separately calculated in two depth zones, between +5 and $-4 \mathrm{~m}$ and between -4 and $-8 \mathrm{~m}$, because the boundary between the deposition zones of gravel and fine sand is approximately at a depth of $4 \mathrm{~m}$.

The total volume of deposited sand was $2.0 \times 10^{6} \mathrm{~m}^{3}$ during the ten years between 1985 and 1995 , giving a mean sand supply from the Abe River of $2.0 \times 10^{5} \mathrm{~m}^{3} / \mathrm{yr}$. This can be used as a boundary condition for longshore sand transport from upcoast. In addition, the rate of increase in sand volume at depths greater than $-4 \mathrm{~m}$ is $1.0 \times 10^{5} \mathrm{~m}^{3} / \mathrm{yr}$. Because fine sand is mainly deposited in this offshore zone, this means that the minimum supply of fine sand is $1.0 \times 10^{5} \mathrm{~m}^{3} / \mathrm{yr}$.

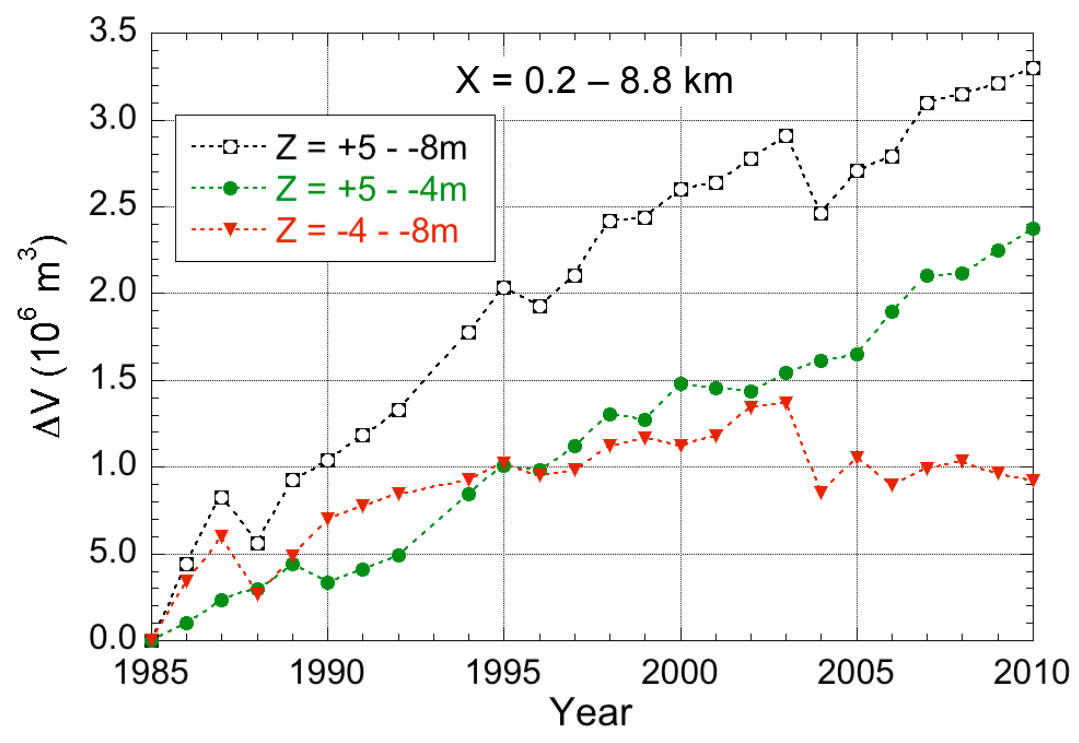

Figure 5. Change in volume of sand deposited in the depth zone between +5 and $-8 \mathrm{~m}$ between $X=0.2$ and $8.8 \mathrm{~km}$ since 1985 .

\section{CALCULATION CONDITIONS}

For the prediction of topographic changes, the contour-line-change model considering the changes in grain size (Uda and Serizawa, 2010) was used. The calculation domain is the $14 \mathrm{~km}$ stretch between the Abe River mouth and the L-shaped groin at $X=14 \mathrm{~km}$ of the entire $17 \mathrm{~km}$ coastline of the Shizuoka and Shimizu coasts. Here, the L-shaped groin has the effect of a fixed boundary because the movement of gravel is fully blocked, although fine sand is transported toward the submarine canyon offshore of the tip of the groin. The topography with straight parallel contours, determined from the topography in 1968, was given as the initial topography. The seabed slope was assumed to be $1 / 10$ in the zone shallower than $-4 \mathrm{~m}$ and $1 / 50$ deeper than $-4 \mathrm{~m}$ on the basis of the measured profiles. The depth of closure and berm height were assumed to be $h_{c}=7 \mathrm{~m}$ and $h_{R}=3 \mathrm{~m}$, respectively. Two characteristic grain sizes of 0.2 and $2 \mathrm{~mm}$ were considered as fine and coarse materials, respectively. Their initial contents were $\mu_{1}=0$ for fine materials and $\mu_{2}=1.0$ for coarse materials in the depth zone between $Z=$ +3 and $-4 \mathrm{~m}$, and $\mu_{1}=1.0$ and $\mu_{2}=0$ in the depth zone between $Z=-5$ and $-7 \mathrm{~m}$. The equilibrium slopes of sand were assumed to be $1 / 50$ for fine materials and $1 / 10$ for coarse materials.

For the wave conditions, waves with an occurrence probability of $5 \%, H_{0}{ }^{\prime}=3 \mathrm{~m}$ and a wave period of $9 \mathrm{~s}$ were incident from the south, and the breaker angle was obtained in the vicinity of headland (HL) No. 1 located at $X=10.5 \mathrm{~km}$, taking the effect of wave refraction into account. On the basis of this calculation, $\theta_{w}$ was set to $7^{\circ}$ between the Abe River mouth and the boundary between the Shizuoka and Shimizu coasts, and $\theta_{w}$ was linearly increased from $7^{\circ}$ at this boundary to $17^{\circ}$ at HL No. 1 and $37^{\circ}$ at the L-shaped groin. Furthermore, the breaker height was reduced so that the longshore component of 
the energy flux was constant and thus, a dynamically stable condition with longshore sand transport of $Q_{0}=2.0 \times 10^{5} \mathrm{~m}^{3} / \mathrm{yr}$ under natural conditions was satisfied.

\begin{tabular}{|c|c|}
\hline \multicolumn{2}{|r|}{ Table 1. Calculation conditions. } \\
\hline Numerical model & $\begin{array}{l}\text { Wave field: directional spreading method for irregular waves with } S_{\max }=25 \text { (Sakai } \\
\text { et al., 2006) } \\
\text { Beach changes: contour-line-change model considering grain size changes (Uda } \\
\text { and Serizawa, 2010) }\end{array}$ \\
\hline Calculation domain & Coast with $17 \mathrm{~km}$ length along Shizuoka and Shimizu coasts \\
\hline Calculation duration & 42 years between 1968 and 2010 \\
\hline Initial bathymetry & $\begin{array}{l}\text { Straight parallel contours using expanded coordinate system based on } \\
\text { bathymetry in } 1968 \\
\text { Seabed slope: } 1 / 10 \text { (shallower than }-4 \mathrm{~m} \text { ) and } 1 / 50 \text { (deeper than }-4 \mathrm{~m} \text { ) }\end{array}$ \\
\hline Grain size Composition & $\begin{array}{l}N=2 \\
\text { Characteristic grain sizes: } d^{(1)}=0.2 \mathrm{~mm} \text { (fine material) and } d^{(2)}=2 \mathrm{~mm} \text { (coarse } \\
\text { material) } \\
\text { Initial content: } \mu_{1}=0.0 \text { (fine), } \mu_{2}=1.0 \text { (coarse) in depth zone between }+3 \mathrm{~m} \text { and - } \\
4 \mathrm{~m} \text {, and } \mu_{1}=1.0 \text { (fine), } \mu_{2}=0.0 \text { (coarse) in depth zone between }-5 \mathrm{~m} \text { and }-7 \mathrm{~m}\end{array}$ \\
\hline Equilibrium slope & $\tan \beta^{(1)}=1 / 50$ (fine) and $\tan \beta^{(2)}=1 / 10$ (coarse) \\
\hline Width of exchange layer & $B=1 \mathrm{~m}\left(B=\Delta h / \tan \beta, \Delta h=0.03 H_{b} \fallingdotseq 0.1\right.$ and $\left.\tan \beta=1 / 10\right)$ \\
\hline Incident wave conditions & $\begin{array}{l}\text { Breaker height } H_{b}=3 \mathrm{~m} \text { and initial breaker angle } \theta_{w}=7^{\circ} \rightarrow 37^{\circ} \\
\theta_{w}=7^{\circ} \text { (Abe River mouth } \rightarrow \text { boundary between Shizuoka and Shimizu coasts) } \\
\theta_{w}=7^{\circ} \rightarrow 17^{\circ} \rightarrow 37^{\circ} \text { (boundary between Shizuoka and Shimizu coasts } \rightarrow \text { artificial } \\
\text { headland No. } 1 \rightarrow \text { L-shaped groin) } \\
\theta_{w}=37^{\circ} \text { (L-shaped groin } \rightarrow \text { Masaki Point) }\end{array}$ \\
\hline Tide condition & M.S.L. $\pm 0.0 \mathrm{~m}$ \\
\hline $\begin{array}{l}\text { Berm height and depth } \\
\text { of closure }\end{array}$ & $h_{R}=3 \mathrm{~m}$ and $h_{c}=7 \mathrm{~m}$ \\
\hline $\begin{array}{l}\text { Sand transport } \\
\text { coefficients }\end{array}$ & $\begin{array}{l}\text { Coefficient of sand transport } A=0.01752 \\
\text { Ozasa and Brampton's (1980) coefficient } \zeta=1.62 \\
\text { Ratio of coefficient of cross-shore sand transport relative to that of longshore } \\
\text { sand transport } K_{z} / K_{x}=0.1\end{array}$ \\
\hline $\begin{array}{l}\text { Depth distribution of } \\
\text { sand transport }\end{array}$ & Cubic equation given by Uda and Kawano (1996) \\
\hline $\begin{array}{l}\text { Critical slope of falling } \\
\text { sand }\end{array}$ & $1 / 2$ on land and $1 / 3$ on seabed \\
\hline $\begin{array}{l}\text { Depth range of } \\
\text { calculation }\end{array}$ & Between $Z=3.5 \mathrm{~m}$ and $-7.5 \mathrm{~m}$ \\
\hline Mesh sizes & $\Delta x=100 \mathrm{~m}$ and $\Delta z=1 \mathrm{~m}$ \\
\hline Time intervals & $\Delta t=1 \mathrm{hr}$ \\
\hline Boundary conditions & $\begin{array}{l}\text { Sand supply from Abe river at right boundary } \\
Q_{\text {in }}=2.5 \times 10^{4} \mathrm{~m}^{3} / \mathrm{yr} \text { (fine material) between } 1968 \text { and } 1983 \\
Q_{\text {in }}=5 \times 10^{4} \mathrm{~m}^{3} / \mathrm{yr} \text { (fine material) }+1.5 \times 10^{5} \mathrm{~m}^{3} / \mathrm{yr} \text { (coarse material) between } 1983 \\
\text { and } 2010 \\
\text { Free boundary at left end: } d q_{x} / d x=0 \text {, seaward and landward end: } q_{z}=0\end{array}$ \\
\hline $\begin{array}{l}\text { Beach nourishment } \\
\text { conditions }\end{array}$ & $\begin{array}{l}\text { Source of sand along }+3 \mathrm{~m} \text { and } 0 \mathrm{~m} \text { contours } \\
\text { Contents of nourishment sand: } \mu_{1}=0.25 \text { (fine) and } \mu_{2}=0.75 \text { (coarse) }\end{array}$ \\
\hline Numerical method & Explicit finite difference method \\
\hline Other remarks & $\begin{array}{l}\text { Wave transmission coefficient } K_{t}=0.7 \text { for detached breakwaters located at } Y= \\
30 \mathrm{~m} \text { (regarding many isolated detached breakwaters as a continuous } \\
\text { breakwater) } \\
\text { Artificial headlands No. } 1-\text { No. } 5: K_{t}=0.5 \\
\text { Seawall between Abe River mouth and HL No. } 1 \\
Y=-35 \mathrm{~m} \text { between } X=0 \text { and } 9.0 \mathrm{~km} \\
Y=-35 \mathrm{~m} \text { to }-150 \mathrm{~m} \text { between } X=9.0 \text { and } 11.0 \mathrm{~km}\end{array}$ \\
\hline
\end{tabular}


For the right boundary condition, sand supply of $2.0 \times 10^{5} \mathrm{~m}^{3} / \mathrm{yr}$ was assumed at the south boundary on the basis of the change in volume since 1983 on the Shizuoka coast, as shown in Fig. 5. On the other hand, beach nourishment using sand dredged from the riverbed of the Abe River and the beach at the north end of the Mihono-matsubara sand spit, where excessive sand has been deposited, has been carried out on the Shimizu coast since 1989, and this volume of nourishment sand was taken into account in the calculation. Table 1 shows the calculation conditions.

\section{RESULTS OF REPRODUCTION CALCULATION}

Given the parallel contours along the expanded coordinate system as the initial bathymetry on the basis of the bathymetry in 1968, as shown in Fig. 6(a), and assuming that the fluvial sand supply from the Abe River was reduced from $2.0 \times 10^{5} \mathrm{~m}^{3} / \mathrm{yr}$ before 1968 to $2.5 \times 10^{4} \mathrm{~m}^{3} / \mathrm{yr}$ after 1968 because of sand mining in the riverbed, the bathymetry in 1983 was reproduced. The reproduced bathymetry and the changes from the initial bathymetry are shown in Figs. 6(b) and 6(c), respectively. Because the balance between sand supply from the upcoast boundary and northward longshore sand transport was lost, erosion began from a location near the Abe River mouth and the erosion zone gradually expanded northward.

Then, the beach changes until 2010 were calculated under the condition that the amount of sand supply recovered to $2.0 \times 10^{5} \mathrm{~m}^{3} / \mathrm{yr}$ in 1983 then remained constant owing to the prohibition of riverbed

(a) Initial bathymetry in 1968

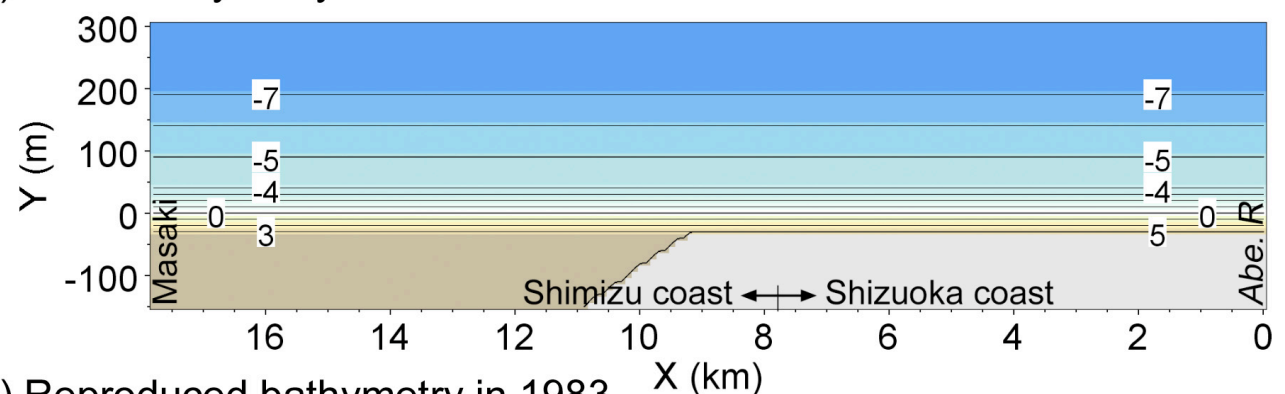

(b) Reproduced bathymetry in 1983
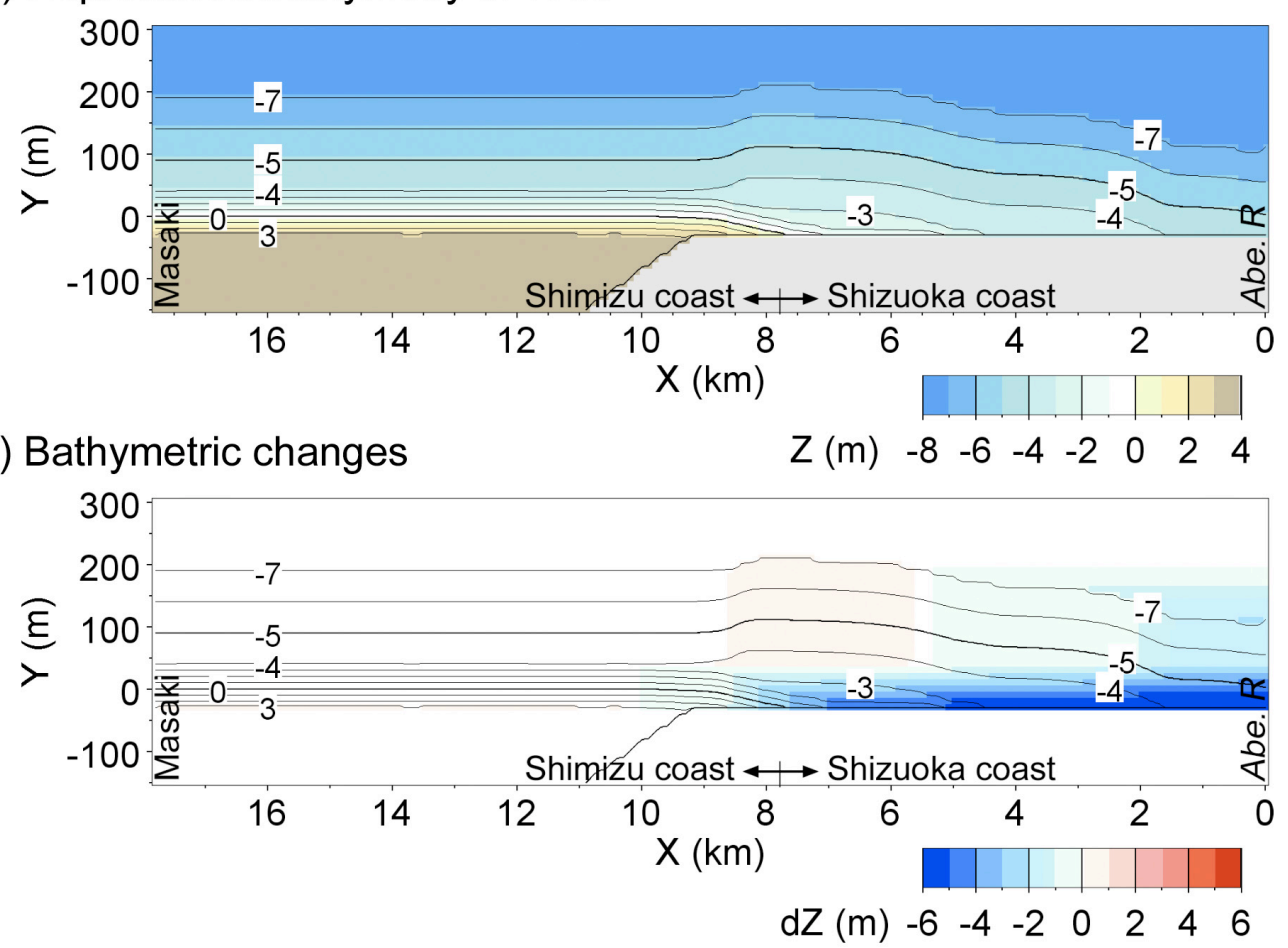

Figure 6. Results of reproduction calculation ((a) initial bathymetry with parallel contours, (b) reproduced bathymetry in 1983 and (c) bathymetric changes until 1983). 
mining. Figures 7(a), 7(b) and 7(c) show the predicted bathymetry in 2010 and the calculated and measured bathymetric changes of the entire Shizuoka and Shimizu coasts until 2010 with reference to the bathymetry in 1983, respectively. In the study area, the fluvial sand from the Abe River was gradually transported northward while being deposited behind the detached breakwaters, and beach erosion occurred downcoast of the detached breakwaters owing to the blockage of northward longshore sand transport.

Because artificial headlands constituting of a couple of detached breakwaters were constructed on the Shimizu coast, the contours of the Shimizu coast had a zigzag shape at each artificial headland, and severe erosion occurred immediately downcoast of these structures. Furthermore, wide sand deposition zone was formed upcoast of the 100-m-long L-shaped groin. The measured and predicted bathymetric changes are in good agreement.

Figure 8 shows the measured and predicted shoreline changes in the study area until 2010 with reference to the shoreline in 1983. Sand supplied from the Abe River mouth was transported northward while forming a river delta; the shoreline advance gradually decreased northward from the river mouth. In addition, a zigzag-type shoreline due to the construction of the artificial headlands and L-shaped groin was formed. The calculated and measured shoreline changes including the shoreline advance on the Shizuoka coast and the shoreline recession on the Shimizu coast, except in the vicinity of the Abe River mouth, are in good agreement.

(a) Predicted bathymetry in 2010

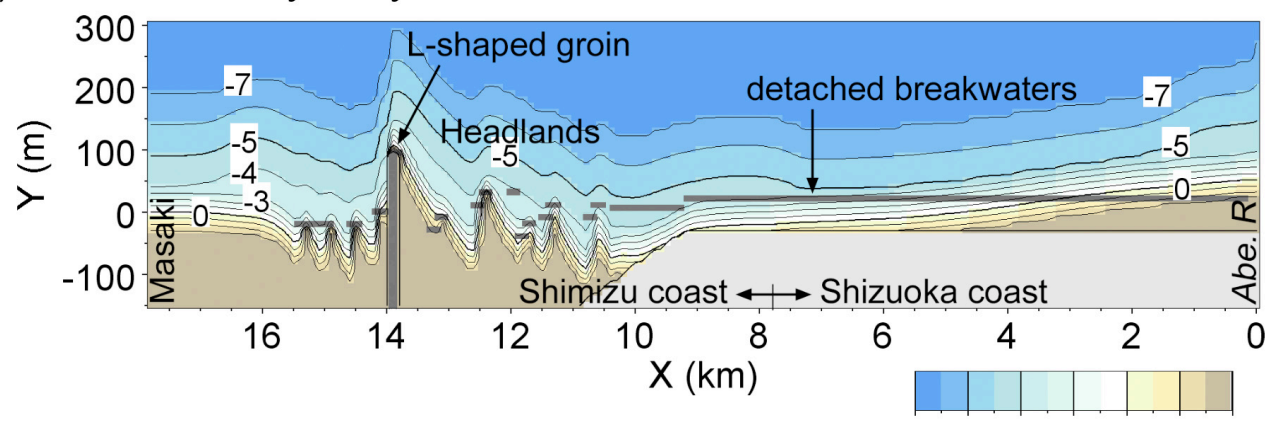

(b) Calculated bathymetric changes

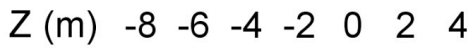

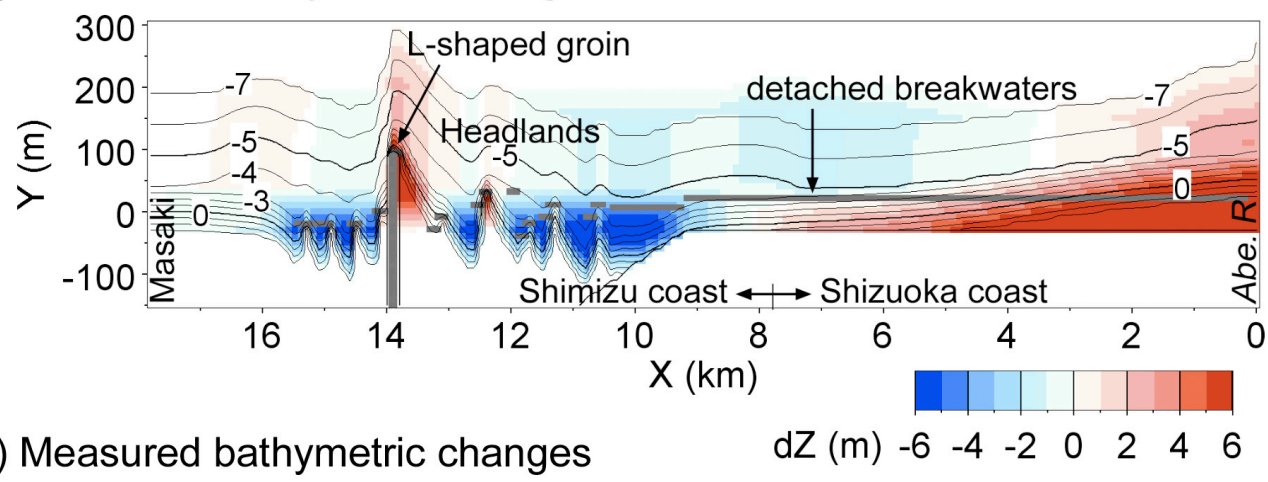

(c) Measured bathymetric changes $\quad d z(m)-6 \quad-4 \quad-2 \quad 0 \quad 2 \quad 4 \quad 6$

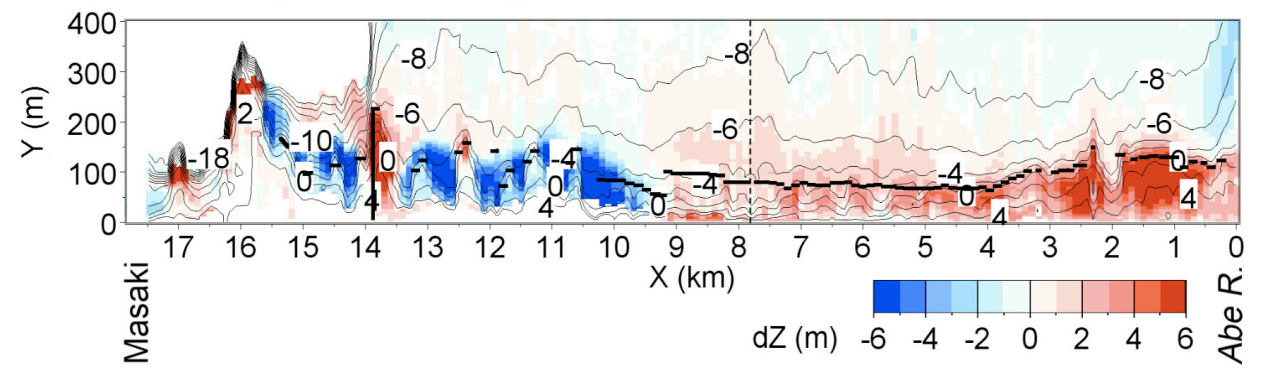

Figure 7. Predicted bathymetry in $\mathbf{2 0 1 0}$ and calculated and measured bathymetric changes of entire Shizuoka and Shimizu coasts until 2010 with reference to bathymetry in 1983. 
(a) 1990

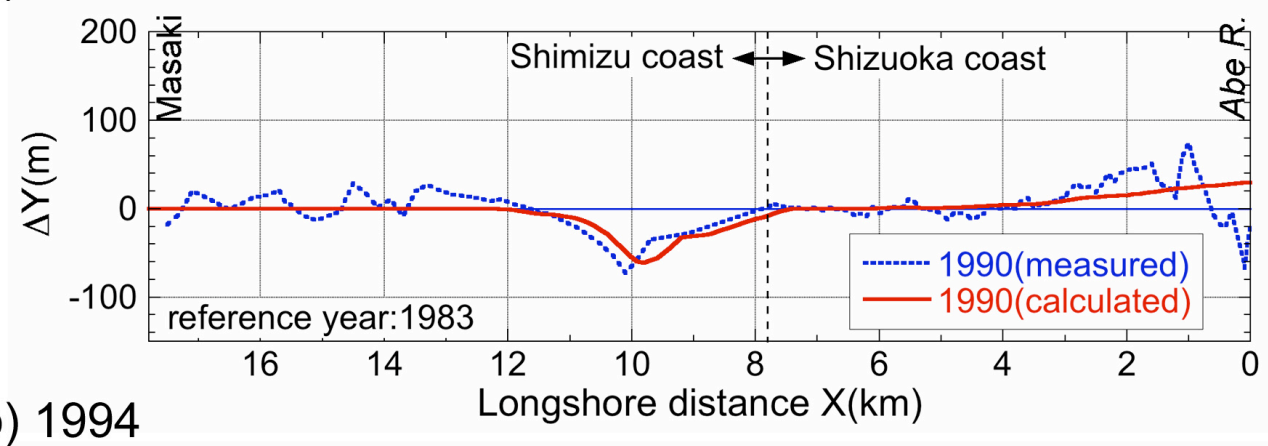

(b) 1994

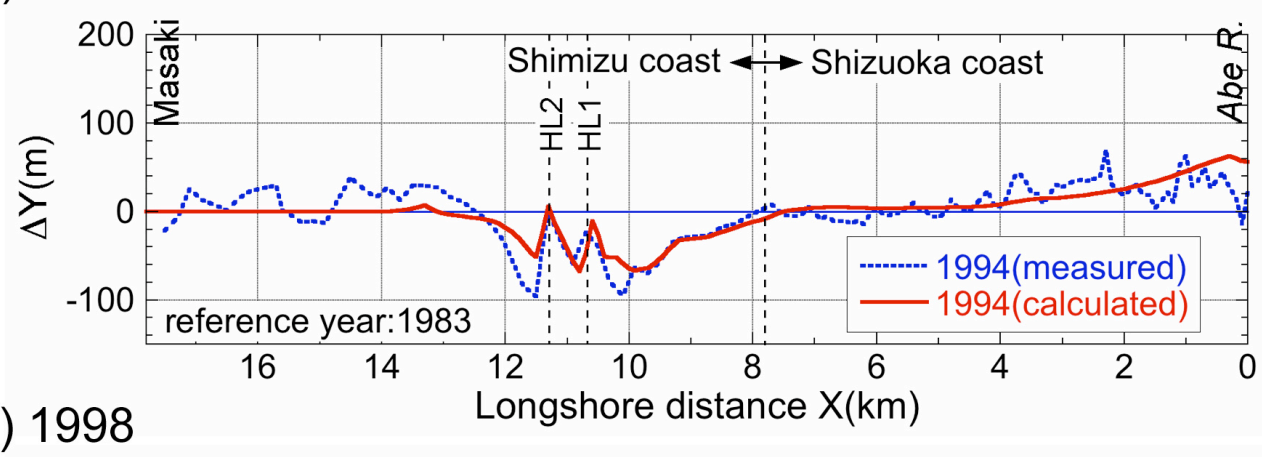

(c) 1998

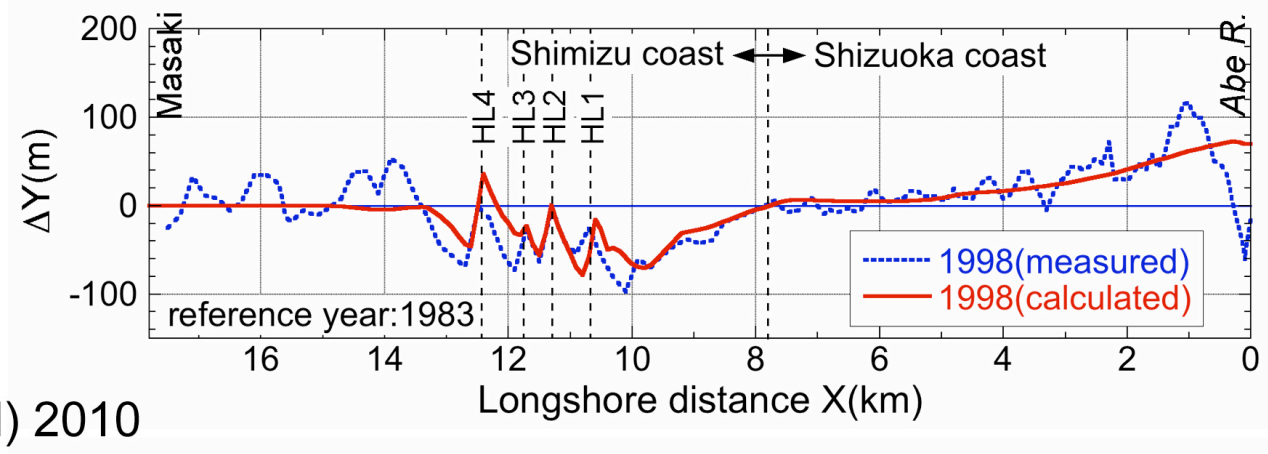

(d) 2010

Longshore distance $\mathrm{X}(\mathrm{km})$

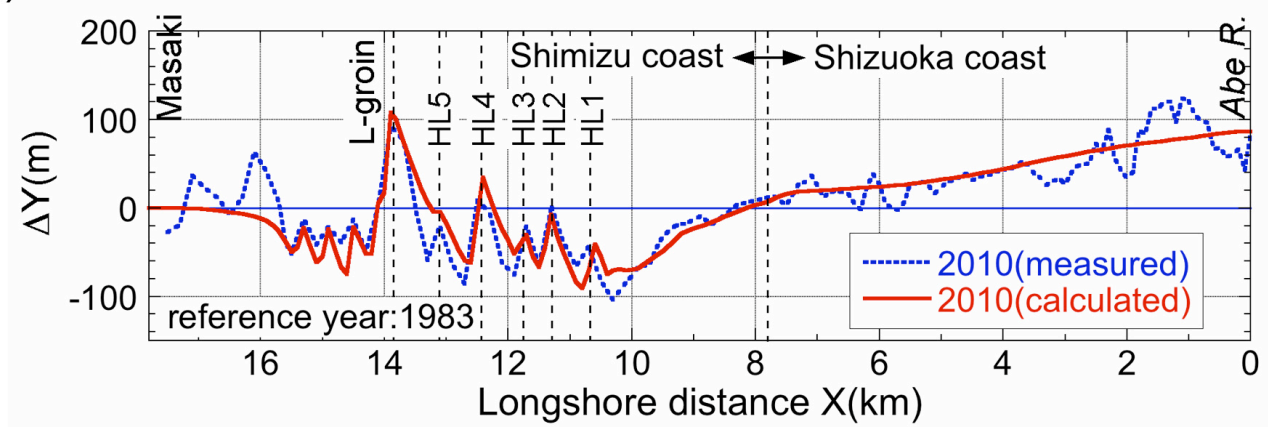

Figure 8. Measured and predicted shoreline changes until 2010 with reference to shoreline in 1983.

\section{PREDICTION OF BEACH CHANGES IN THE NEXT 20 YEARS}

\section{Continuation of present beach nourishment}

Beach nourishment was carried out at an average rate of $5.46 \times 10^{4} \mathrm{~m}^{3} / \mathrm{yr}$ around the artificial headlands on the Shimizu coast between 1998 and 2009 as a measure against beach erosion. Figure 9 shows the predicted bathymetry in 2030 in the case of maintaining the same amount of beach nourishment as in the past. Figures 9 (a) and 9(b) show the predicted bathymetry and the changes from the initial bathymetry, respectively. 
(a) Predicted bathymetry in 2030

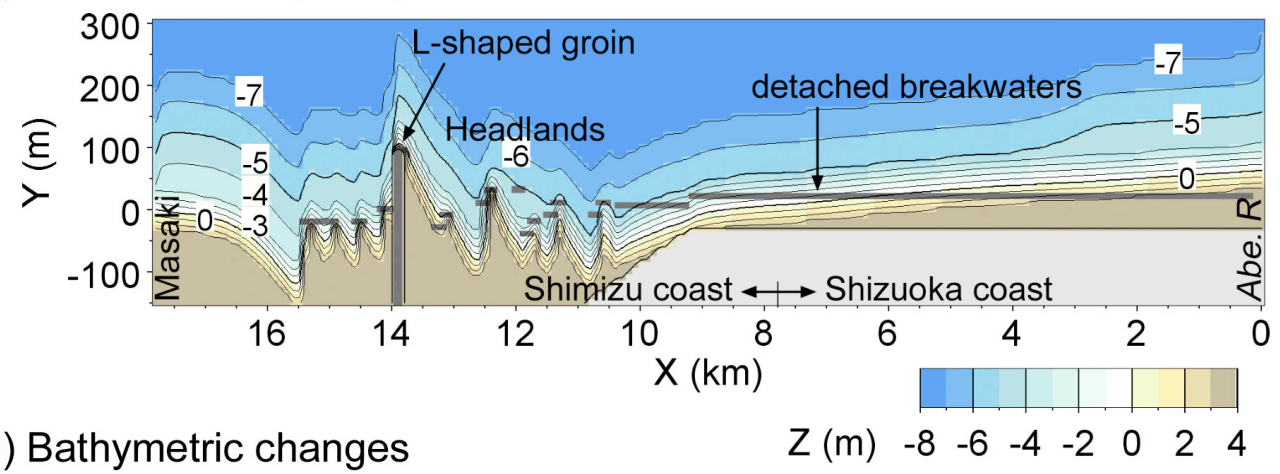

(b) Bathymetric changes

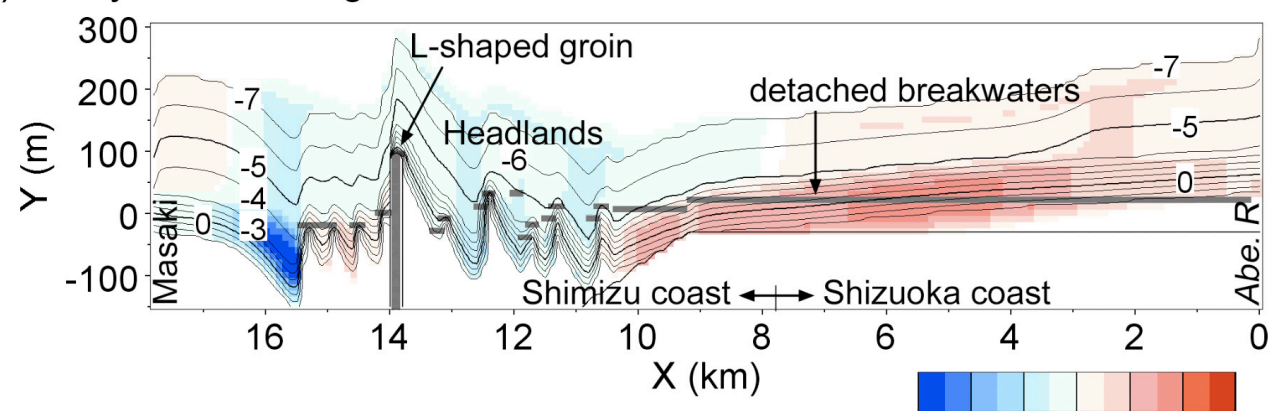

(c) Shoreline changes

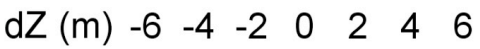

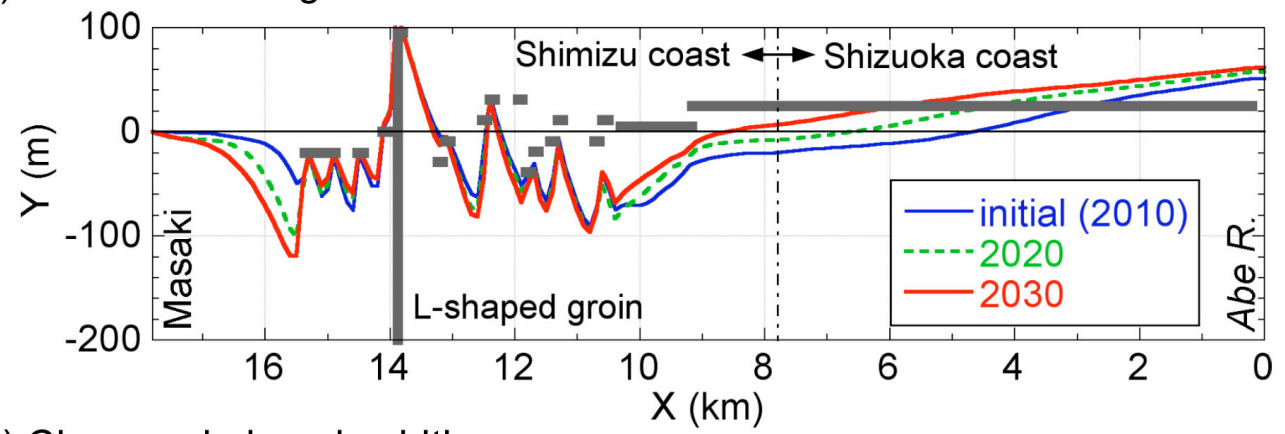

(d) Changes in beach width

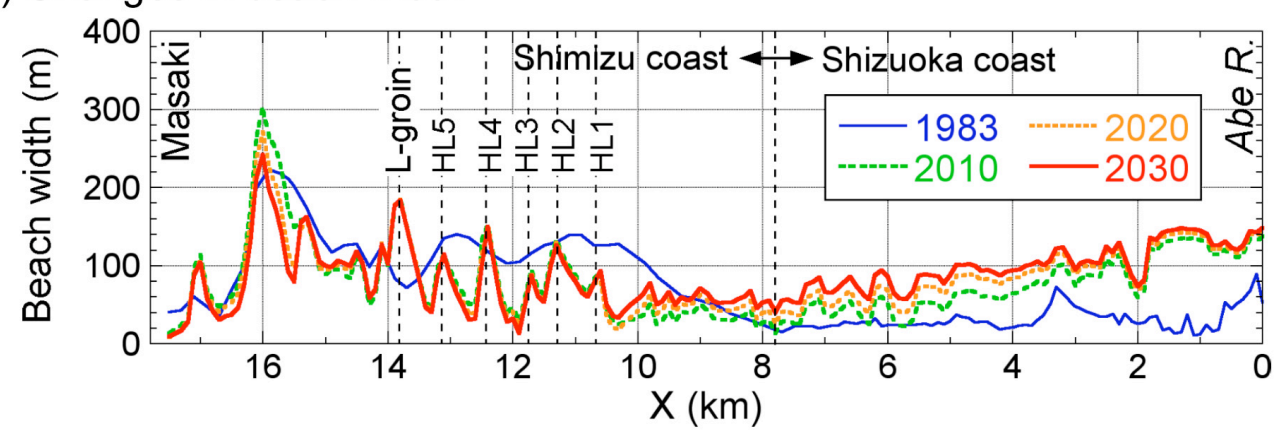

Figure 9. Predicted beach changes in 2030 ((a) predicted bathymetry in 2030, (b) bathymetric changes with reference to that in 2010, (c) predicted shoreline in 2030 with reference to that in 1968 and (d) changes in beach width in the case of maintaining the same amount of beach nourishment as in the past).

Sand supplied from the Abe River is transported northward mainly behind the detached breakwaters, and sand is deposited up to the boundary between the Shizuoka and Shimizu coasts, whereas beach erosion is still severe around the artificial headlands north of this sand deposition zone. The area where the beach width increases is limited to the area behind the detached breakwaters, and shoreline recession continues near the north end of the sand spit (Figs. 9(c) and 9(d)). In particular, detached breakwaters were buried under the sandy beach between the Abe River mouth and $X=5 \mathrm{~km}$ 
(Fig. 9(c)), and the beach width increased up to $150 \mathrm{~m}$ at $X=1 \mathrm{~km}$ where almost no sandy beach existed in 1983 because of sand deposition (Fig. 9(d)).

\section{Effect of increase in sand supply from Abe River}

Because the beach changes until 2010 were reproduced well, the beach changes for the following 20 years were predicted in the case of increasing the sand supply to $2.5 \times 10^{5} \mathrm{~m}^{3} / \mathrm{yr}, 25 \%$ larger than the present level. Figures 10(a) and 10(b), respectively, show the predicted bathymetry and the changes from the initial topography. The shoreline of the Abe River delta markedly advances while burying the detached breakwaters built north of the Abe River mouth under the sandy beach because of the large amount of sand supplied from the Abe River. The effect of the increase in the amount of sand supply, however, is concentrated in the vicinity of the river mouth with less effect on the Shimizu coast far from the river mouth. This situation is also clear in the shoreline changes shown in Fig. 10(c).

Thus, even if a large amount of sand, greater than the amount annually supplied from the Abe River under natural conditions, is artificially supplied, its effect is limited to near the river mouth without any obvious effect further downcoast. A similar result was observed when the sand supply from the Tenryu River was artificially increased (Miyahara et al., 2010). Thus, it was concluded that the changes in the fluvial sand supply from the Abe River, which is $8 \mathrm{~km}$ from the most severely eroded site on the Shimizu coast, are independent of the beach changes at the most severely eroded site,

(a) Predicted bathymetry in 2030

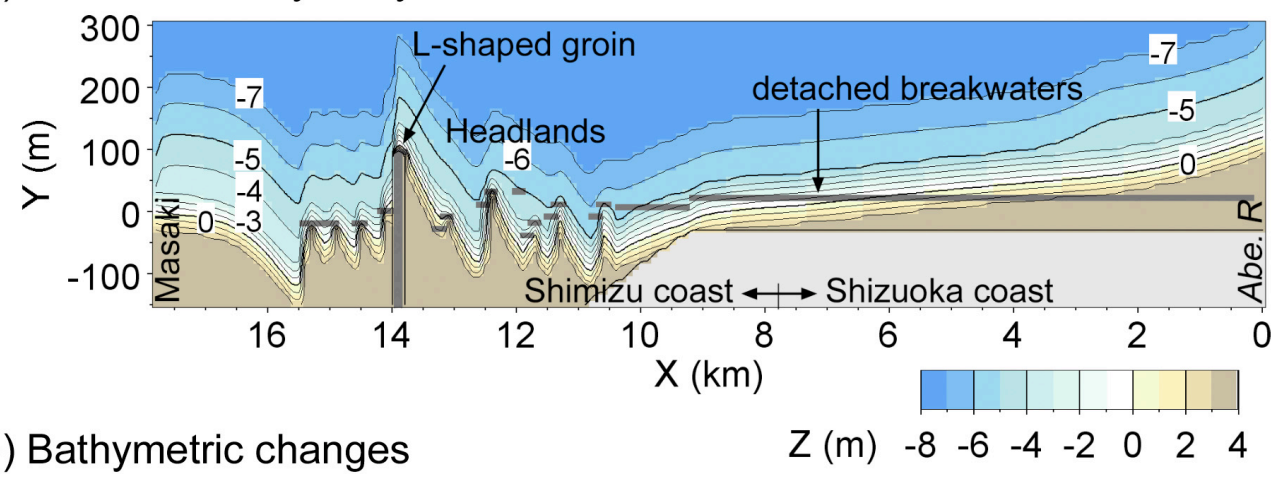

(b) Bathymetric changes

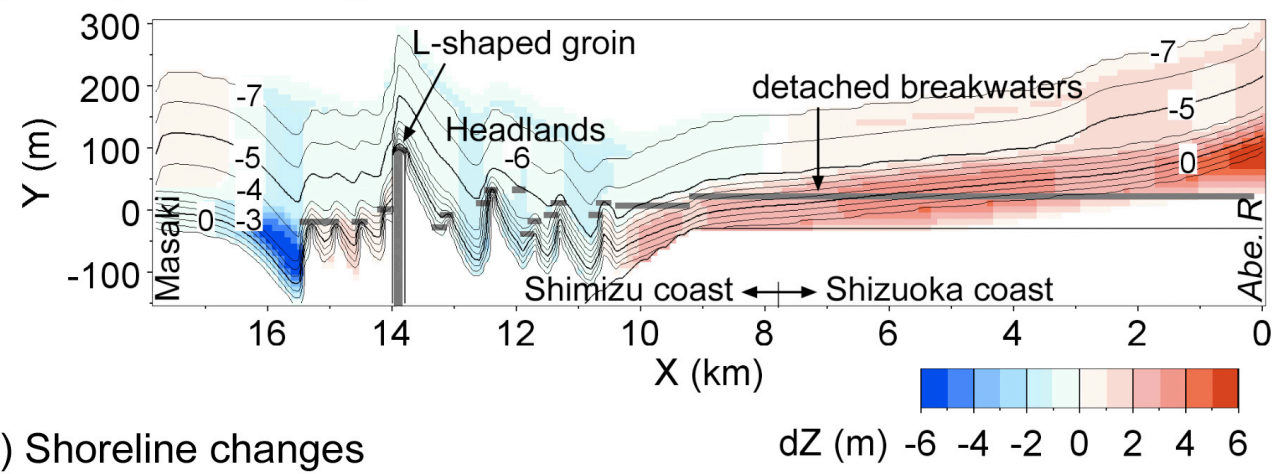

(c) Shoreline changes

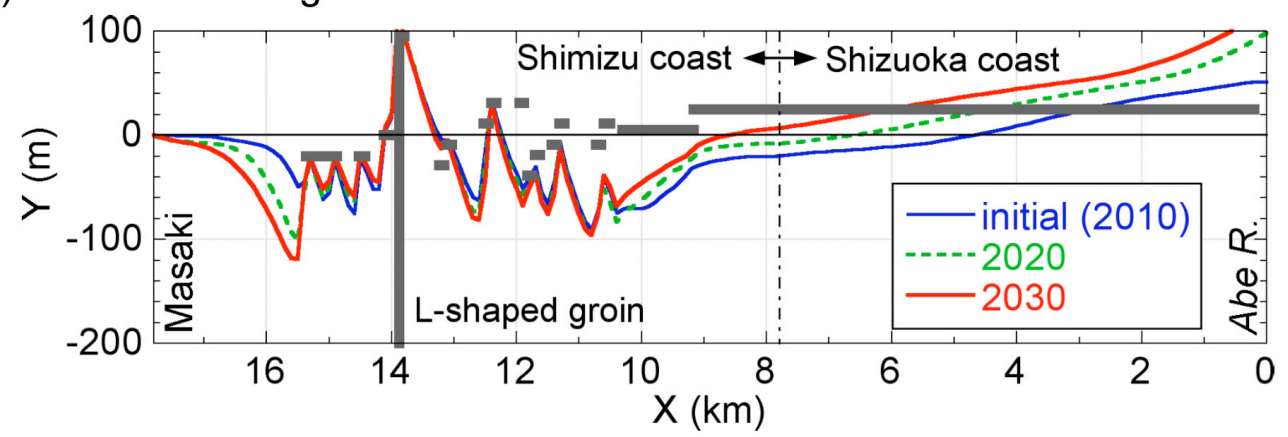

Figure 10. Predicted beach changes in 2030 when sand supply was increased to $2.5 \times 10^{5} \mathrm{~m}^{3} / \mathrm{yr}, 25 \%$ larger than the present level ((a) predicted bathymetry in 2030, (b) bathymetric changes with reference to that in 2010 and (c) shoreline changes with reference to that in 1968). 
and local beach nourishment is required near the eroded site owing to the fact that many detached breakwaters have already been constructed.

\section{CONCLUSIONS}

The long-term beach changes between 1968 and 2010 on the entire Shizuoka and Shimizu coasts, which were formed by fluvial sand supply from the Abe River, were successfully reproduced using the contour-line-change model considering changes in grain size. In this calculation, not only the movement of the sand body but also the three-dimensional bathymetric changes was reproduced. In our previous paper related to the movement of the sand body, the calculation was carried out given the bathymetry in 1983 before the generation of the sand body as a solid bed. In the present study, the bathymetry measured in 1968 under natural conditions before erosion was selected as the initial bathymetry, and the bathymetry in 2010 was predicted. The predicted and measured bathymetries were in good agreement. Then, the effect of an increase in sand supply from the Abe River on recovering the sandy beach of the Shizuoka and Shimizu coasts was quantitatively investigated. It was concluded that the increase in fluvial sand supply from the Abe River, which is $8 \mathrm{~km}$ from the most severely eroded site on the Shimizu coast, is independent of the beach changes at the most severely eroded site, and local beach nourishment must be continued at the eroded site to maintain the beaches. Finally, it was concluded that the present model is a useful tool for predicting long-term beach changes on a long coast with a curved shoreline.

\section{REFERENCES}

Fukuhama, M., T. Uda, K. Yamada, M. Serizawa, T. San-nami, and T. Ishikawa. 2009. Prediction of development of sand body and movement of fine sand offshore of detached breakwaters, Proc. Coastal Dynamics 2009, Paper No. 39, pp. 1-12.

Miyahara, S., T. Uda, K. Furuike, M. Serizawa, T. San-nami, and T. Ishikawa. 2010. Effect of sand bypassing at Sakuma dam in Tenryu River as a measure against erosion of Tenryu delta coast, Proc. 32nd ICCE, sediment.106, pp.1-12.

Nishitani, M., T. Uda, M. Serizawa, and T. Ishikawa. 2008. Measurement and prediction of deformation of conveyer belts carrying gravel and fine sand off Shimizu coast, Proc. 31st ICCE, pp. 2570-2582.

Ozasa, H., and A. H. Brampton. 1980. Model for predicting the shoreline evolution of beaches backed by seawalls, Coastal Eng., Vol. 4, pp. 47-64.

Sakai, K., T. Uda, M. Serizawa, T. Kumada, and Y. Kanda. 2006. Model for predicting threedimensional sea bottom topography of statically stable beach, Proc. 30th ICCE, pp. 3184-3196.

Uda, T., and S. Kawano. 1996. Development of a predictive model of contour line change due to waves, Proc. JSCE, No. 539/ II -35, pp. 121-139. (in Japanese)

Uda, T., M. Serizawa, M. Nishitani, and T. Ishikawa. 2008. Field investigation and numerical simulation of movement of sand body, Proc. 31st ICCE, pp. 2051-2063.

Uda, T., and M. Serizawa. 2010. Model for predicting topographic changes on coast composed of sand of mixed grain size and its applications, in 'Numerical simulations - examples and applications in computational fluid dynamics’ Angermann, L. ed., INTEC, pp. 327-358.

Uda, T. 2010. Japan's Beach Erosion - Reality and Future Measures, World Scientific, 418 pp. 